DOI: https://doi.org/10.24127/ajpm.v10i2.3642

\title{
KOMUNIKASI IDE MATEMATIS GAYA BELAJAR VISUAL DAN KINESTETIK DALAM PEMBELAJARAN ONLINE
}

\author{
Zukhrufurrohmah $^{1 *}$, Akhsanul In'am², Dian Cahyaningasri ${ }^{3}$, \\ ${ }^{1 *}, 2,3$ Universitas Muhammadiyah Malang, Malang, Indonesia \\ * Jl. Raya Tlogomas No. 246, 65144, Malang, Indoneisa. \\ E-mail: $\quad$ zukhrufurrohmah@umm.ac.id ${ }^{\left.{ }^{*}\right)}$ \\ akhsanul@umm.ac.id ${ }^{2)}$ \\ diancahyaningasri@gmail.com $^{3)}$
}

Received 27 March 2021; Received in revised form 23 June 2021; Accepted 02 July 2021

\begin{abstract}
Abstrak
Penelitian ini bertujuan untuk mendeskripsikan kemampuan komunikasi ide matematis gaya belajar visual dan kinestetik pada pembelajaran online dalam menyelesaikan masalah terkait geometri. Penelitian ini merupakan penelitian diskriptif dengan pendekatan kualitatif. Teknik pengumpulan data yang digunakan ialah angket, tes, dan wawancara. Subjek penelitian adalah 77 mahasiswa Pendidikan Matematika semester V yang menempuh mata kuliah Geometri Analitik. Dua mahasiswa dari setiap gaya belajar secara acak dipilih yang memiliki kemampuan komunikasi ide matematis katagori baik dan cukup untuk kemudian diwawancara. Analisis data hasil pengisian angket gaya belajar dilakukan secara kuantitatif. Sedangkan data hasil tes dianalisis dengan mengkategorikan hasil pengerjaan maahsiswa berdasar keterpenuhinya indikator komunikasi ide matematis, hasil wawancara digunakan sebagai data penegas dan pelengkap hasil tes. Hasil penelitian menunjukkan bahwa kemampuan komunikasi ide matematis gaya belajar visual berbeda dengan gaya belajar kinestetik. Subjek dengan gaya belajar visual memiliki kemampuan komunikasi ide matematis lebih baik dibandingkan gaya belajar kinestetik pada pembelajaran online materi geometri analitik. Subjek yang memiliki gaya belajar visual lebih dominan menguasai indikator kedua terutama dalam menulis prosedur penyelesaian masalah secara runtun. Sedangkan subjek dengan gaya belajar kinestik tidak memiliki penguasaan secara dominan pada indikator komunikasi ide matematis.
\end{abstract}

Kata kunci: Gaya belajar; komunikasi ide matematis; pembelajaran online.

\begin{abstract}
This study aims to describe the ability to communicate mathematical ideas of visual and kinesthetic learning styles in online learning in solving problems related to geometry. This research is a descriptive study with a qualitative approach. Data collection techniques used are questionnaires, tests, and interviews. The research subjects were 77 students of Mathematics Education in the fifth semester who took the Analytical Geometry course. Two students from each learning style were randomly selected who had excellent and sufficient mathematical idea communication skills to be interviewed. Data analysis of the results of filling out the learning style questionnaire was carried out quantitatively. While the test results data were analyzed by categorizing the results of student work based on the fulfillment of mathematical idea communication indicators, interview results were used as confirming data and complementary test results. The results showed that communicating mathematical ideas with visual learning styles was different from kinesthetic learning styles. Subjects with visual learning styles have better mathematical idea communication skills than kinesthetic learning styles in online learning of analytic geometry material. Subjects with a visual learning style are more dominant in mastering the second indicator, especially in writing sequential problem-solving procedures. In contrast, the subject with the kinesthetic learning style does not have a dominant mastery of the communication indicators of mathematical ideas.
\end{abstract}

Keywords: Learning style; mathematical idea communicatio; online learning.

This is an open access article under the Creative Commons Attribution 4.0 International License 
DOI: https://doi.org/10.24127/ajpm.v10i2.3642

\section{PENDAHULUAN}

Pembelajaran merupakan pembelajaran yang menekankan sebuah proses, dimana proses tersebut memiliki hubungan timbal balik dalam mencapai hasil dan tujuan tertentu. Sejalan dengan Fitrah, (2017); Kabael, (2012); MoyerPackenham et al., (2019), menyatakan bahwa selama proses belajar mengajar matematika tidak hanya berorientasi pada hasil akhir, melainkan setiap tahapan memiliki mekanisme berpikir untuk mengevaluasi serta mencari kebenaran terhadap suatu informasi. Oleh karena itu, pembelajaran matematika perlu ditekankan agar hasil yang diterima relevan dalam kehidupan sehari-hari dan dapat terapkan sesuai kebutuhan (Iriani \& Leni, 2013; Gitriani et al., 2018).

Salah satu hal yang berkaitan erat dalam proses pembelajaran matematika adalah kemampuan komunikasi matematis (Kabael, 2012; Uptegrove, 2015). Komunikasi matematis adalah suatu proses dalam menyampaikan ide, strategi, dan solusi pada penyelesaian masalah matematika baik secara tertulis maupun lisan (Khadijah et al., 2018; Nurmantoro, 2017). Menurut Ulya et al., (2019), perlu dilakukan suatu penekanan komunikasi matematis pada pembelajaran matematika agar individu tidak kesulitan jika menemui berbagai permasalahan matematis dalam kehidupan.

Cara mengkomunikasi ide matematis setiap individu berbeda-beda dan dapat dipengaruhi oleh gaya belajar (Aisami, 2015; An \& Carr, 2017; Soflano et al., 2015). Gaya belajar adalah cara individu dalam menerima, memproses, dan mengolah informasi yang diterima ketika belajar (Aisami, 2015; Rezaeinejad. et al., 2015). Bosni \& Nan (2013) serta Hamdani (2015) menyatakan bahwa terdapat tiga karakteristik dalam gaya belajar yaitu visual, auditorial, dan kinestetik. Masrifah (2020) menyatakan lebih lanjut bahwa berbagai karakteristik gaya belajar memiliki pengaruh terhadap proses belajar dan kemampuan komunikasi ide matematis.

Pada sisi lain, saat ini bidang pendidikan juga beradaptasi dengan adanya penyebaran COVID 19, tidak terkecuali di Indonesia. Pemerintah membuat kebijakan agar kegiatan belajar mengajar dialihkan menjadi pembelajaran online untuk mencegah penyebaran virus (Hong et al., 2021; Patricia, 2020). Seluruh jenjang pendidikan termasuk perguruan tinggi melaksanakan pembelajaran jarak jauh dengan memanfaatkan learning management system, zoom meeting atau platform online lainnya (Masfingatin et al., 2021).

Berbagai penelitian selama pembelajaran jarak jauh banyak membahas tentang hambatan, dampak, hingga analisis stress yang dialami siswa selama melakukan pembelajaran online (Anugrahana, 2020; Loviana \& Baskara, 2020; Maulana \& Iswari, 2020). Sedangkan penelitian Putri et al., (2021) dan Djunaedy (2020) lebih fokus pada penerapan metode pembelajaran online pada masa Pandemi COVID-19. Penelitian lain yang mendiskusikan tentang kemampuan komunikasi matematis siswa adalah penelitian Daimaturrohmatin \& Rufiana (2019) dengan tipe gaya belajar berdasar kategori Kolb. Penelitian pada masa pembelajaran online belum banyak membahas tentang kemampuan komunikasi ide matematis mahasiswa pada materi geometri analitik. Oleh karena itu, artikel ini menyajikan secara deskrisptif kemampuan mahasiswa mengkomunikasikan ide matematis 
dalam menyelesaikan permasalahan kontesktual materi geometri analitik.

Pembelajaran online menjadikan keterbatasan interaksi antara mahasiswa dan dosen dalam melakukan proses kegiatan belajar mengajar (Mishra et al., 2020; Patricia, 2020). Faktanya sebagaian besar kegiatan pembelajaran online dilakukan melalui audio visual seperti PPT bersuara atau youtube yang mana kegiatan pembelajaran didominasi dengan mendengarkan (audiotorial) (Ramdhan et al., 2020). Kegiatan pembelajaran yang didominasi dengan mendengarkan video pembelajaran kurang disenangi oleh siswa dengan gaya belajar visual dan kinestetik (Zahroh \& Asyhar, 2014). Kegiatan pembelajaran ini dapat mempengaruhi proses pembelajaran, kemampuan dan hasil belajar mahasiswa (Maulah et al., 2020; Maulana \& Iswari, 2020). Hal ini dapat pula mempengaruhi kemampuan komunikasi matematis mahasiswa. Di sisi lain, mahasiswa penting memiliki kemampuan komunikasi ide matematis yang baik dalam menyelesaikan permasalahan (I. D. Wijayanti et al., 2019).

Upaya peningkatan kemampuan komunikasi ide matematis dalam pembelajaran online perlu diawali dengan melakukan analisis kemampuan komunikasi ide matematis. Pengajar atau dosen perlu mengetahui sejauh mana kemampuan mahasiswanya untuk merancang kegaitan perbaikan yang tepat (Kleden, 2013; Paridjo et al., 2018). Oleh karena itu hasil penelitian ini diharapkan dapat menambah khasanah keilmuan untuk menambah alternatif variasi kegiatan pembelajaran jarak jauh selama pandemi sehingga setiap mahasiswa dapat terfasilitas.

Berdasarkan

paparan

permasalahan, hasil penelitian sebelumnya dan solusi yang ditawarkan, tujuan penelitian ialah mendeskripiskan kemampuan komunikasi ide penyelesaian masalah matematika mahasiswa dengan gaya belajar visual dan kinestetik ketika pembelajaran online.

\section{METODE PENELITIAN}

Penelitian ini merupakan penelitian diskriptif pendekatan kualitatif untuk mendeskripsikan kemampuan komunikasi ide matematis dalam memecahkan masalah Geometri Analitik ditinjau dari perbedaan gaya belajar Visual, dan Kinestetik. Subjek penelitian ini adalah 77 mahasiswa Pendidikan Matematika semester V yang menempuh mata kuliah Geometri Analitik secara online melalui platform Learning Management System, elmu.umm.ac.id, dan Zoom Meeting secara bergantian.

Penelitian diawali dengan studi literatur untuk mengkaji cakupan materi geometri, teori gaya belajar, penelitian yang telah ada, dan indikator kemampuan komunikasi matematis yang digunakan. Materi geometri analitik dipilih karena memiliki potensi untuk memunculkan kemampuan komunikasi siswa. Hasil studi literatur berupa instrument penelitian; 1) lembar soal kontekstual untuk mengukur kemampuan komunikasi matematis tulis, 2) lembar wawancara untuk melengkapi dan mengkonfirmasi data hasil tes, dan 3) lembar angket gaya belajar untuk mengetahui gaya belajar mahasiswa. Instrumen kemudian divalidasi kepada validator. Lembar soal dan lembar wawancara telah dinyatakan valid oleh validator, dosen prodi pendidikan matematika yang juga mendampingi perkuliahan geometri analitik secara online. Sedangkan lembar angket yang diambil dari (Penger \& Tekavčič, 2009) 
diterjemahkan dalam Bahasa Indonesia dan telah dinyatakan valid oleh ahli bahasa.

Selanjutnya pada langkah pengambilan data, dilakukan dengan memberikan angket gaya belajar melalui google form, kemudian pada hari berbeda siswa menyelesaikan soal pada lembar tes melalui platform elmu.umm.ac.id dengan waktu pengerjaan 2 jam untuk memberi waktu menyiapkan jawaban dan mengunggah pada platform. Wawancara dilakukan melalui Zoom Meeting setelah hasil pekerjaan soal dikategorikan berdasar indiaktor komunikasi matematis yang terpenuhi oleh mahasiswa. Subjek wawancara dipilih 2 mahasiswa sebagai perwakilan masing-masing gaya belajar kinestetik dan visual yang berkategori baik dan cukup dalam pengerjaan tes. Mahasiswa berkategori baik dalam pengerjaan tes jika memenuhi minimal 3 indikator kemampuan komunikasi ide matematis, sedangkan kategori kurang ketika terpenuhi paling banyak 3 indiaktor. Hasil pengisian lembar angket gaya belajar dianalisis sesuai ketentuan (Penger \& Tekavčič, 2009) sehingga diperoleh hasil pemetaan mahasiswa berdasar gaya belajarnya. Hasil pengerjaan soal tes dianalisis berdasar ketercapaian indikator komunikasi matematis, ditunjukkan pada Tabel 1. Sedangkan hasil wawancara digunakan untuk melengkapi data hasil pengerjaan tulis mahasiswa.

Tabel 1. Indikator komunikasi ide matematis

\section{No Indikator Komuniasi Ide Matematis}

Mampu mengubah pernyataan pada soal kedalam ide matematis. Indikator ini

1. dapat dilihat ketika mahasiswa menuliskan informasi yang diketahui dan ditanya pada soal.

Mampu menuliskan prosedur penyelesaian masalah dengan runtun dan benar.

2. Indikator ini dapat dilihat ketika mahasiswa mengerjakan soal, apakah langkah atau aturan yang digunakan logis.

Mampu menggunakan simbol matematika dengan benar secara tertulis. Indikator

3. ini dapat dilihat ketika mahasiswa menggunakan simbol matematika saat menulis jawaban.

Mampu mengungkapkan kesimpulan akhir dari jawaban permasalahan sesua

4. pertanyaan. Indikator ini dapat dilihat ketika mahasiswa memberikan kesimpulan akhir jawaban yang sesuai dengan pertanyaan pada soal.

\section{HASIL DAN PEMBAHASAN}

Berdasarkan hasil pengisian angket gaya belajar diperoleh bahwa terdapat 35 mahasiswa memiliki gaya belajar visual, dan sebanyak 22 mahasiswa memiliki gaya belajar kinestetik. Kemudian dipilih masingmasing 2 mahasiswa dari setiap gaya belajar secara acak. Subjek tersebut adalah mahasiswa yang memiliki gaya belajar visual dan kinestetik dengan mengelompokkan gaya belajar dari hasil angket gaya belajar. Kemudian dikelompok lagi untuk mahasiswa yang mendapatkan skor baik dan cukup dari hasil tes. Hasil pengerjaan soal tes dari mahasiswa terpilih kemudian dianalisis berdasar indikator komunikasi ide matematisnya. Hasil analisis ini dipadukan dengan hasil wawancara yang dilakukan setelah mahasiswa menyelesaikan soal tes. Subjek 
penelitian terpilih memiliki kode visual baik (VB), visual cukup (VC), kinestetik Baik (KB), dan kinestetik Cukup (KC).

\section{Gaya Belajar Visual}

Dari 35 mahasiswa yang memiliki gaya belajar visual diperoleh capaian dari indiaktor yang dominan tidak terpenuhi atau yang paling banyak terpenuh kemampuan komunikasi ide matematis yakni dua puluh dua mahasiswa berkatagori baik, dan empat mahasiswa yang berkatagori cukup. Pemilihan hanya kategori kemampuan komunikasi ide matematis baik dan cukup dikarenakan kedua kategori tersebut sudah mewakili kategori lainnya. Penjabaran lebih lanjut mengenai kemampuan komunikasi ide matematis ditinjau gaya belajar visual dengan katagori baik dan cukup sebagai berikut.

Komunikasi ide matematis subjek penelitian gaya belajar visual baik (VB)

Mahasiswa dengan gaya belajar visual kategori baik (VB) dapat memenuhi tiga sampai empat indikator komunikasi ide matematis dengan tepat. Hal ini dapat dilihat dari hasil jawaban VB pada soal tes nomor 2. Soal tes nomor 2 disajikan pada Gambar 1. Pada soal tes nomor 2 mahasiswa diminta untuk mencari persamaan elips dari panjang dan lebar yang sudah diketahui pada soal. Sehingga mahasiswa harus mengetahui terlebih dahulu mengenai konsep persamaan elips. Hasil pengerjaan VB pada soal nomor 2 disajikan pada Gambar 2.

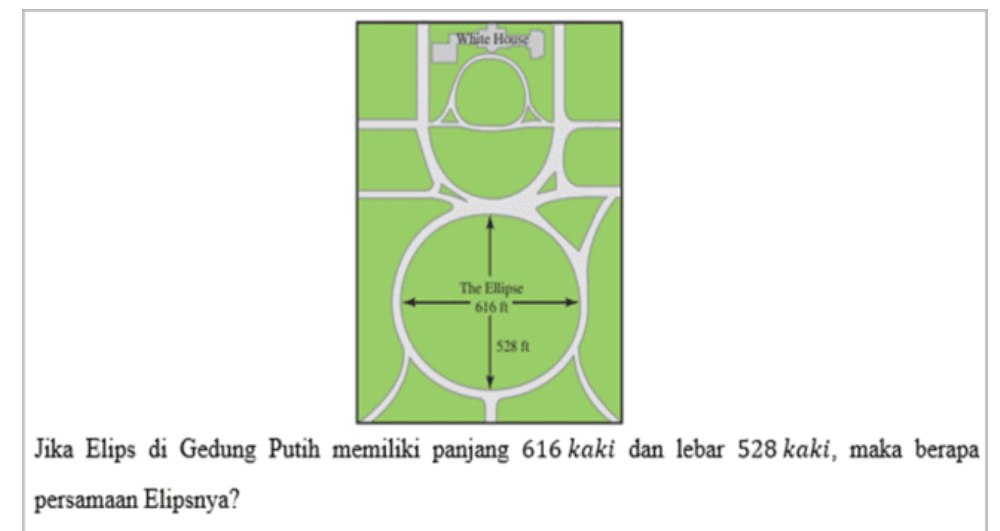

Gambar 1. Soal tes nomor 2.

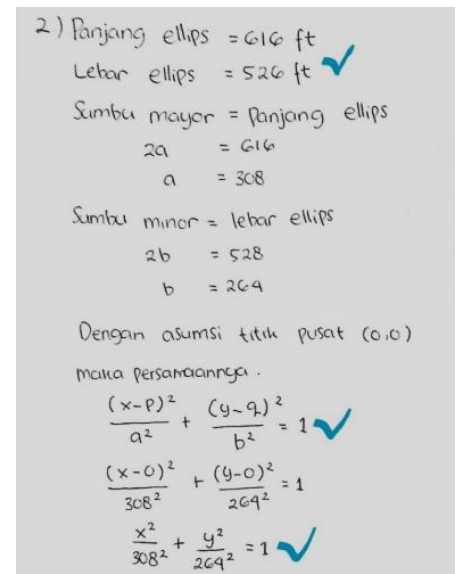

Gambar 2. Hasil tes subjek penelitian VB nomor 2 
DOI: https://doi.org/10.24127/ajpm.v10i2.3642

Pada Gambar 2 VB menuliskan informasi yang diketahui dan dicari dari soal yang diberikan. VB juga menuliskan prosedur penyelesaian secara runtut dan rapi dengan ketepatan menggunakan simbol matematis. Namun, pada akhir pengerjaan menunjukkan bahwa VB tidak menuliskan simpulan pada akhir pengerjaan. Berdasarkan wawancara, VB merasa bahwa jawaban yang diberikan sudah jelas dalam menjawab pertanyaan. Sehingga VB tidak memberikan tambahan lagi mengenai jawaban yang sudah didapat. Hal ini sejalan dengan penelitian Rizqi et al.,
(2016), menyatakan bahwa siswa yang yakin akan kemampuannya dalam menyelesaikan sebuah permasalahan termasuk siswa yang memiliki kepercayaan diri tinggi. Selain itu, kecenderuangan untuk tidak menuliskan simpulan atau penegas jawaban biasanya siswa tersebut sudah sangat percayaan diri dengan jawaban yang didapat (Nurul et al., 2019).

Berbeda dengan pengerjaan soal nomor 3. Pada pengerjaan soal nomor 3, VB dapat memenuhi keempat indikator komunikasi ide matematis. Soal tes nomor 3 disajikan pada Gambar 3.

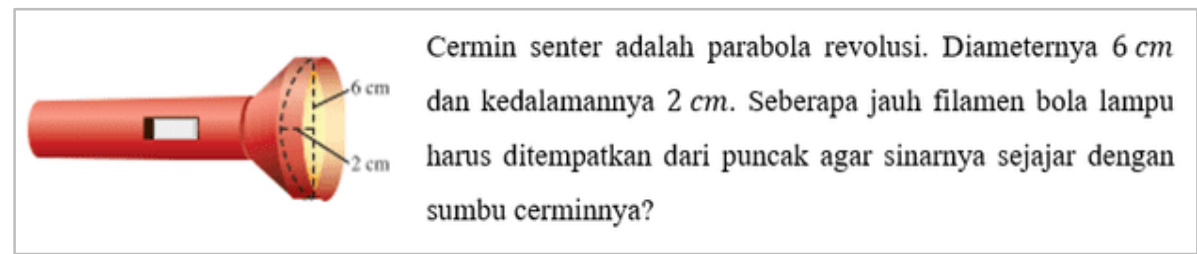

Gambar 3. Soal tes nomor 3

Pada soal tes nomor 3, merefleksi kembali mengenai konsep mahasiswa diminta untuk menemukan parabola menghadap kekanan. jarak filamen lampu dari puncak agar Pengerjaan VB nomor 3 disajikan pada sinar senter sejajar dengan sumbu Gambar 4. cermin. Sehingga mahasiswa harus

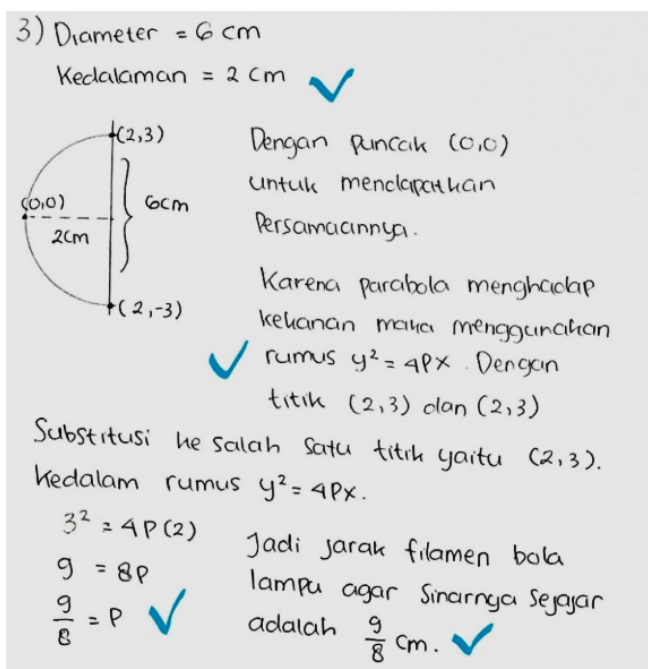

Gambar 4. Hasil tes subjek penlitian VB nomor 3

Pada Gambar 4, sama seperti pengerjaan nomor 2 dimana VB menuliskan informasi yang diketahui dan dicari dari soal yang diberikan. VB 
juga menulis prosedur penyelesaian secara runtut dan rapi dengan ketepatan menggunakan simbol matematis. Selain itu, VB memberikan jawaban sesuai dengan permasalahan yang diberikan. Pada akhir jawaban, mahasiswa menuliskan simpulan sebagai penegas jawaban persoalan yang diberikan. Berdasarkan wawancara VB dapat menyampaikan dengan tepat alasan pemilihan prosedur yang dituliskan. VB juga menyatakan bahwa gambar ilustrasi (visual) yang digambar membantu memahami masalah dan menyelesaikan soal. Hal ini sejalan dengan penelitian Aisami, (2015), yang menunjukkan bahwa sebagian besar korteks sensorik manusia dikhususkan untuk penglihatan, dimana bagian otak yang digunakan untuk memproses suatu kata lebih kecil dibandingkan dengan bagian yang memproses gambar visual.

Komunikasi ide matematis mahasiswa gaya belajar visual cukup (VC)

Mahasiswa dengan gaya belajar visual katagori cukup (VC) tidak dapat memenuhi keempat indikator komunikasi ide matematis. Hal ini dapat dilihat dari hasil jawaban VC pada soal tes nomor 3. Soal tes dapat dilihat pada Gambar 3. Pengerjaan VC nomor 3 disajikan pada Gambar 5.

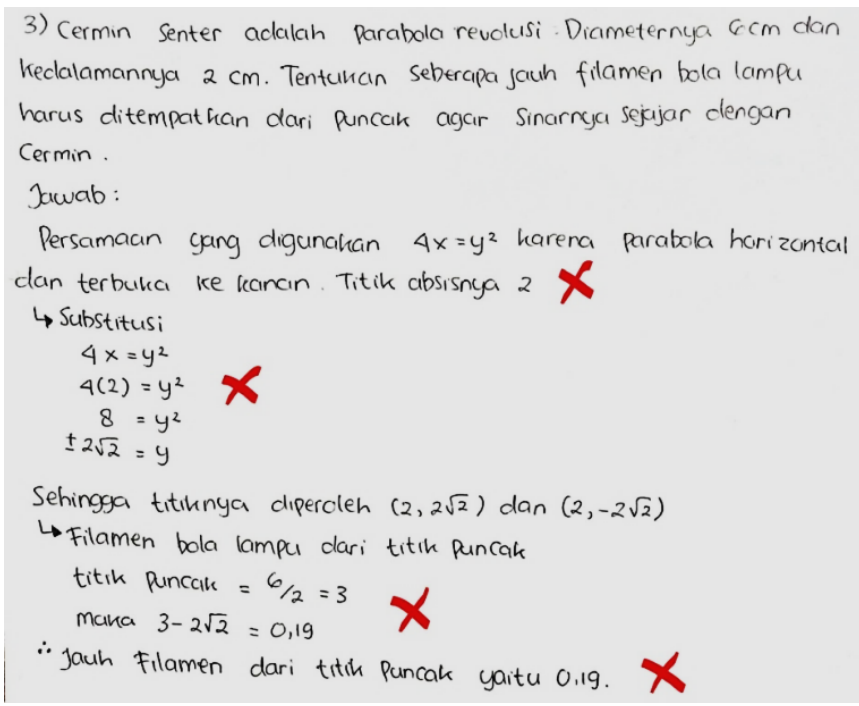

Gambar 5. Hasil tes subjek penelitian VC nomor 3

Pada Gambar 5, VC tidak menuliskan informasi yang diketahui dan dicari dari soal yang diberikan. VC menulis prosedur penyelesaian secara runtut dan rapi akan tetapi tidak memperoleh jawaban dengan benar. Diakhir pengerjaan VC menuliskan kesimpulan dari apa yang sudah didapat. Berdasarkan wawancara VC tidak terlalu yakin dengan apa yang sudah dikerjakan. VC mengungkapkan bahwa ia mengalami kesulitan dalam menemukan rumus yang tepat untuk menyelesaikan soal. Dengan kata lain, kesulitan mahasiswa dalam memahami soal dan menentukan langkah penyelesaian yang tepat mengakibatkan kurang baiknya komunikasi penyelesaian masalah yang dituliskan. Hal ini sejalan dengan penelitian Achir et al., (2017), yang menunjukan bahwa siswa yang belum menafsirkan solusi matematika yang diperoleh, memiliki kemampuan komunikasi ide matematis tulis dengan katagori rendah-sedang. 
DOI: https://doi.org/10.24127/ajpm.v10i2.3642

Mengenai hasil perngerjaan soal nomor 3 VC melakukan hal yang sama pada soal nomor 4. VC tidak dapat memenuhi keempat indikator kemampuan komunikasi ide matematis. Soal serta hasil jawaban mahasiswa pada soal nomor 4, disajikan pada Gambar 6 dan Gambar 7.

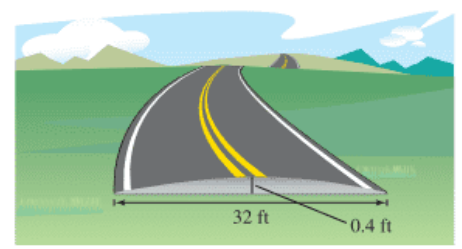

Jalan sering kali dirancang dengan permukaan parabola untuk memungkinkan hujan turun. Jalan tertentu yang lebarnya $32 \mathrm{kaki}$ adalah 0,4 kaki lebih tinggi di bagian tengah daripada di sisinya (lihat gambar).

(a) Tentukan persamaan parabola yang memodelkan permukaan jalan. (Asumsikan bahwa titik asal berada di tengah jalan).

(b) Seberapa jauh permukaan jalan dari tengah jalan lebih rendah 0,1 kaki dari pada di tengah?

Gambar 6. Soal tes nomor 4

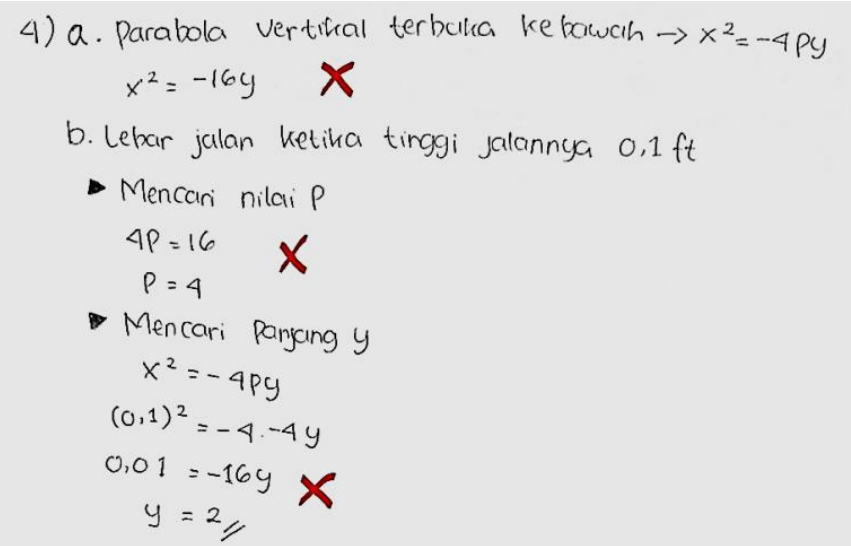

Gambar 7. Hasil tes subjek penelitian VC nomor 4

Pada soal nomor 4 mahasiswa diminta untuk menentukan persamaan parabola dan jarak dari permukaan jalan dari tengah jalan dengan ketentuan jalan lebih rendah 0,1 kaki. Sehingga subjek penelitian diminta untuk refleksi mengenai konsep parabola menghadap kebawah. Secara keseluruhan Gambar 7 hampir sama dengan pengerjaan soal pada nomor 3. VC tidak menuliskan informasi yang diketahui dan dicari dari soal yang diberikan. Selain itu, kurang ketepatan VC dalam menggunakan rumus dan simbol matematis menyebabkan hasil yang didapat tidak menjawab permasalahan yang diberikan. VC juga tidak menuliskan kesimpulan akhir pada hasil pengerjaan soal. Berdasarkan hasil wawancara VC mengungkapkan bahwa ia tidak dapat memahami maksud soal. VC juga kebingungan dalam mengidentifikasi informasi yang diketahui pada soal. Sehingga sama halnya ketika VC mengerjakan nomor 3 dimana $\mathrm{VC}$ mengerjakan menurut pemahaman sendiri. Hal ini sejalan dengan penelitian Sari \& Aripin, (2018), yang menunjukan bahwa siswa yang mengalami kesulitan dalam menyelesaikan suatu masalah seperti kebingungan dan belum mampu mengidentifikasi, disebabkan siswa tersebut tidak melakukan pengkoneksian dalam pemecahan masalah secara maksimal. 


\section{Gaya Belajar Kinestetik}

Dari 22 mahasiswa yang memiliki gaya belajar kinestetik diperoleh capaian dari indiaktor yang dominan tidak terpenuhi atau yang paling banyak terpenuh kemampuan komunikasi ide matematis yakni tujuh mahasiswa berkatagori baik, dan sebelas mahasiswa yang berkatagori cukup. Pemilihan hanya kategori kemampuan komunikasi ide matematis baik dan cukup dikarenakan kedua kategori tersebut sudah mewakili kategori lainnya. Penjabaran lebih lanjut mengenai kemampuan komunikasi ide matematis ditinjau gaya belajar kinestetk dengan katagori baik dan cukup sebagai berikut.

Komunikasi ide matematis mahasiswa gaya belajar kinestetik baik (KB)

Mahasiswa dengan gaya belajar kinestetik katagori baik (KB) dapat memenuhi tiga indikator komunikasi ide matematis dengan tepat. Hal ini dapat dilihat dari hasil jawaban KB pada soal tes nomor 2 seperti pada Gambar 8 .

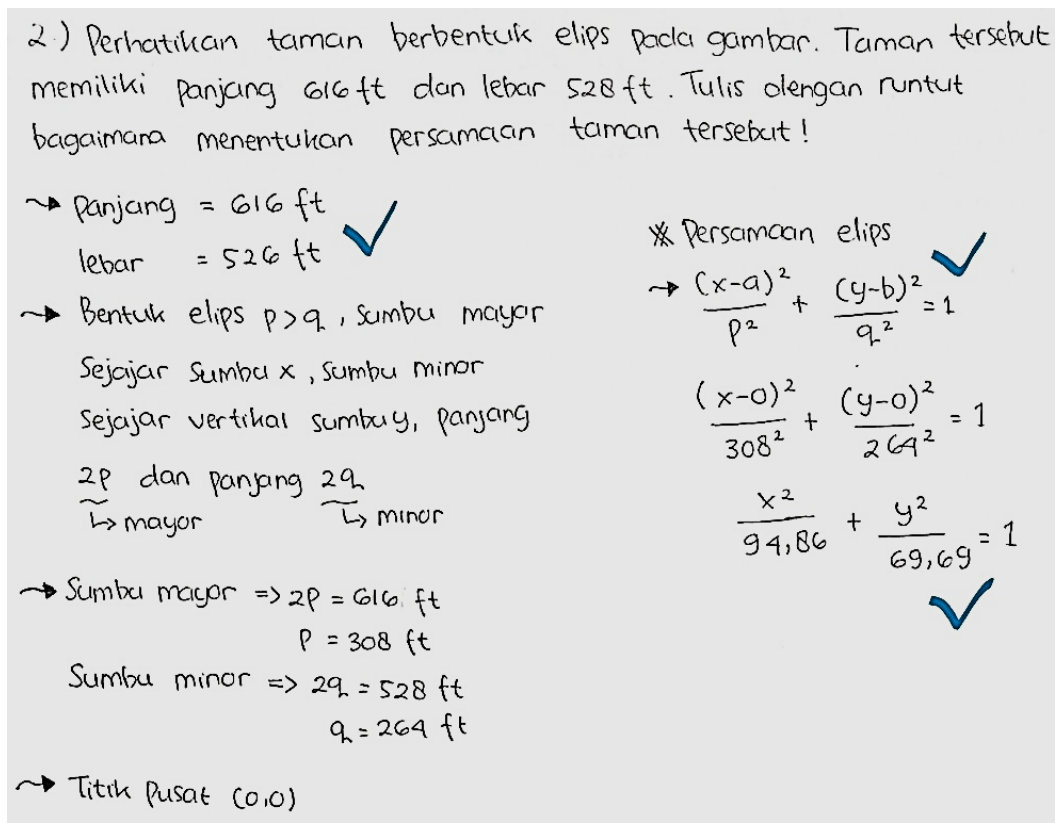

Gambar 8. Hasil tes subjek penelitian KB soal nomor 2

Berdasarkan Gambar 8, KB menuliskan informasi yang diketahui dan dicari dari soal yang diberikan. KB juga menuliskan prosedur penyelesaian secara runtut dan rapi menggunakan simbol matematis hingga memperoleh jawaban dengan benar. Namun, pada hasil bagian akhir KB mengalami sedikit kesalahan dimana hasil penguadratan dari $308^{2}$ dan $246^{2}$ tidak tepat. Sebenarnya pengerjaan KB sudah benar pada tahap kedua dalam persamaan elips yaitu $\frac{(x-0)^{2}}{308^{2}}+\frac{(y-0)^{2}}{264^{2}}=$
1. Pada akhir pengerjaan KB tidak menuliskan kesimpulan akhir pada hasil pengerjaan tes. Berdasarkan wawancara $\mathrm{KB}$ dapat menyampaikan dengan tepat alasan prosedur yang dituliskan. KB tidak menyadari bahwa hasil penguadratannya salah. KB mengungkapkan bahwa ia tidak meneteliti lagi setelah mendapatkan jawaban tersebut. Hal ini sejalan dengan penelitian Saptika et al., (2018), yang menunjukan bahwa siswa yang biasanya tergesa-gesa dalam mengerjaan soal, 
melewatkan tahap pengecakan atau meneliti kembali langkah pengerjaan serta jawaban yang didapat. Selain itu, menurut Ferdianto \& Yesino, (2019), ketergesahan siswa dalam menyelesaikan masalah menyebabkan kelengahan dalam menuliskan kesimpulan.
Sama seperti pengerjaan soal tes nomor 3, dimana KB mampu memenuhi tiga indikator komunikasi ide matematis dengan tepat. Hasil jawaban KB pada soal tes nomor 3 disajikan pada Gambar 9.

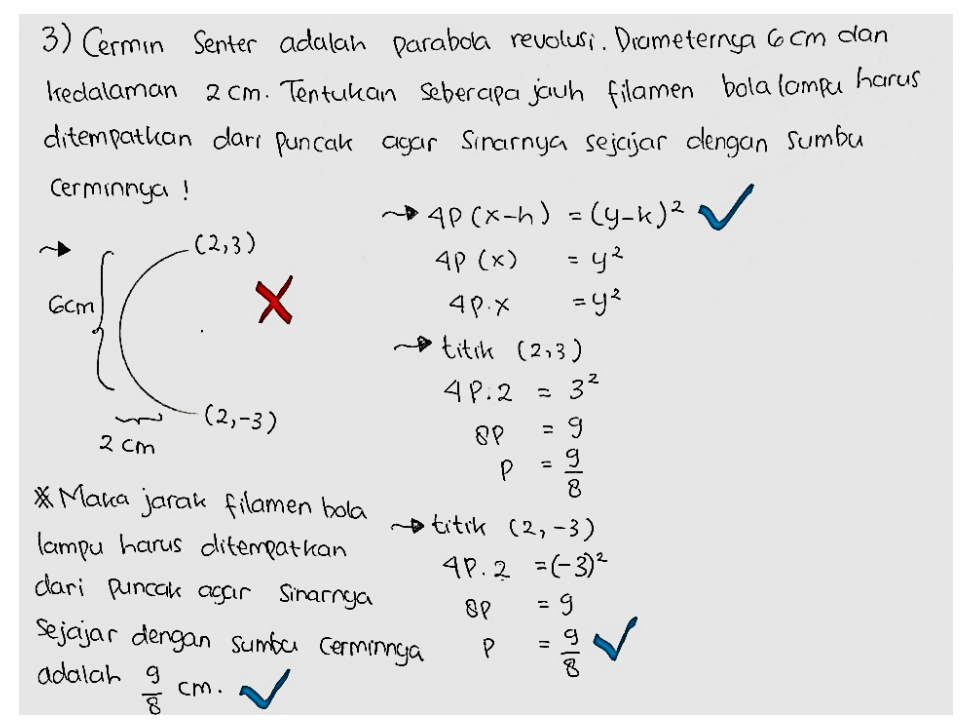

Gambar 9. Hasil tes subjek penelitian KB nomor 3

Berdasarkan Gambar 9, secara keseluruhan hampir sama dengan hasil tes pada nomor 2 akan tetapi KB tidak menuliskan informasi yang diketahui dan dicari dari soal yang diberikan. KB hanya menggambarkan cermin senter dan memperjelas titik koordinat yang dinyatakan pada permasalahan soal. KB menuliskan prosedur penyelesaian secara runtut dan rapi menggunakan simbol matematis hingga memperoleh jawaban dengan benar. KB juga menuliskan kedua titik yang diperoleh yaitu titik $(2,3)$ dan titik $(2,-3)$ serta mencobanya satu-satu pada rumus parabola. Pada akhir pengerjaan KB menuliskan kesimpulan akhir pada hasil pengerjaan soal. Berdasarkan wawancara KB dalam menjelaskan hasil pekerjaannya tidak merasa melakukan kesalahan dan yakin dengan jawaban yang diberikan. KB tidak menuliskan informasi secara rinci karena menurut KB informasi yang ada dalam soal sudah jelas dan tidak perlu menuliskan informasi lagi pada pengerjaan. Hal ini sejalan dengan penelitian Ramadhan \& Minarti, (2018), yang menyatakan bahwa menuliskan infomasi berupa diketahui dan ditanya merupakan hal penting namun banyak yang menyepelekan. Menyelesaikan soal tidak hanya mengutamakan jawaban dengan benar akan tetapi melihat proses siswa ketika mengungkapkan ide untuk menyelesaikan soal.

Komunikasi ide matematis mahasiswa gaya belajar kinestetik cukup $(K C)$

Mahasiswa dengan gaya belajar kinestetik katagori cukup (KC) tidak dapat memenuhi keempat indikator komunikasi ide matematis dengan tepat. Hal ini dapat dilihat dari hasil jawaban KC pada Gambar 10. 


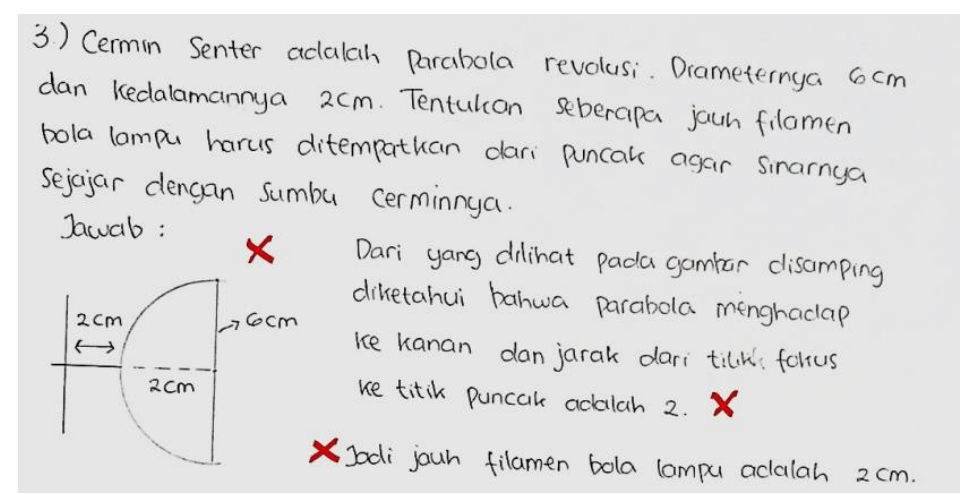

Gambar 10. Hasil tes subjek penelitian KC nomor 3

Pada Gambar 10, KC tidak menuliskan informasi yang diketahui dan dicari dari soal yang diberikan. $\mathrm{KC}$ tidak menulis prosedur penyelesaian dengan simbol matemtis ataupun rumus matematika. Diakhir pengerjaan $\mathrm{KC}$ menuliskan kesimpulan dari apa yang sudah didapat akan tetapi jawaban yang diperolehnya tidak menjawab permasalahan yang diberikan. Berdasarkan wawancara, KC mengungkapkan bahwa $\mathrm{KC}$ kesulitan dalam memahami soal. KC belum pernah menyoba mengerjaan soal Geometri Analitik dalam bentuk soal kontekstual. KC juga tidak mengetahui rumus yang digunakan untuk menyelesaikan soal. Sehingga, KC dalam mengerjakan soal tersebut berdasarkan pemaham sendiri. Hal ini sejalan dengan penelitian Farida, (2015), yang menunjukan bahwa siswa yang mengalami miskonsepsi seringkali mengalami kesalahan dalam menafsirkan solusi hal ini karena siswa tidak memperhatikan apa yang ditanyakan pada soal.

$\mathrm{KC}$ mengalami masalah yang sama pada pengerjaan soal nomor 4. KC tidak dapat memenuhi keempat indikator kemampuan komunikasi ide matematis. Hasil jawaban KC pada soal tes nomor 4 disajikan pada Gambar 11.

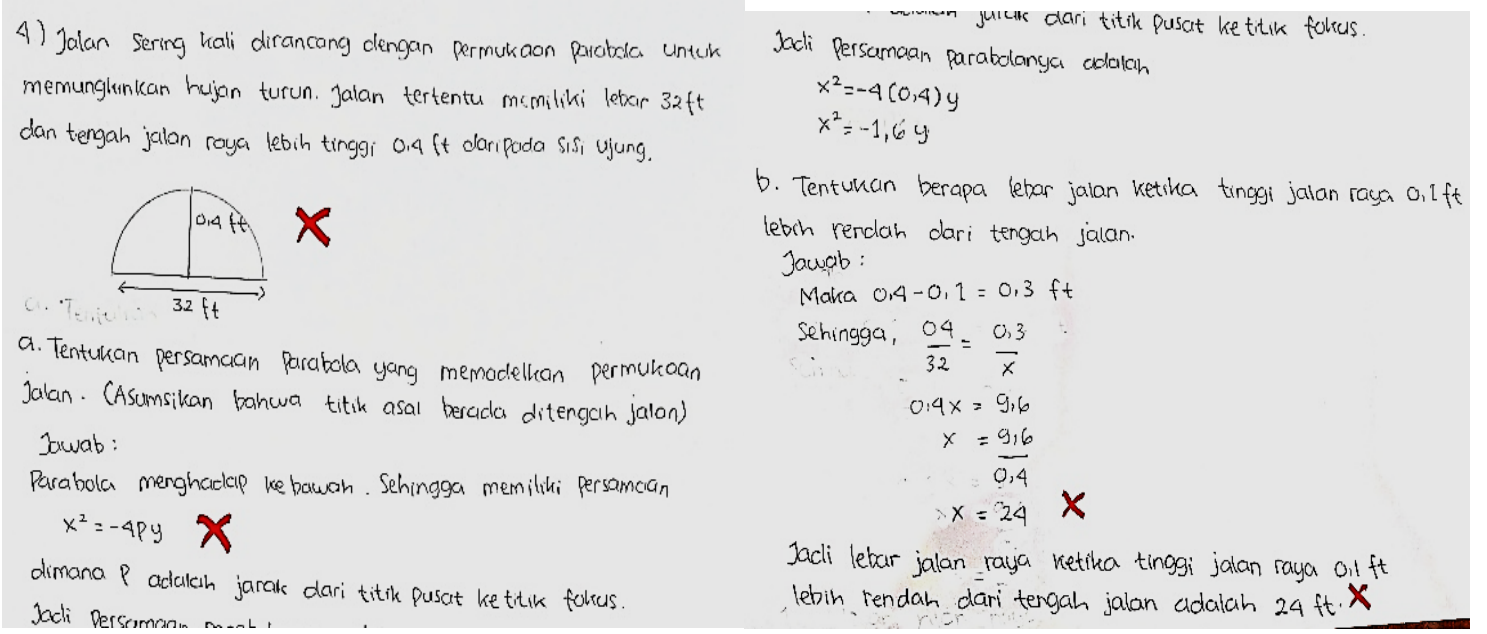

\section{Gambar 11. Hasil tes subjek penelitian KC nomor 4}

Berdasarkan Gambar 11, secara keseluruhan hampir sama dengan hasil tes pada nomor 3 dimana KC tidak menuliskan informasi yang diketahui dan dicari dari soal yang diberikan. KC menulis prosedur penyelesaian secara 
runtun dan rapi dengan ketepatan menggunakan simbol matematis. Namun pada pengerjaan KC untuk soal a, KC memperoleh jawaban dengan benar akan tetapi untuk soal b, KC tidak memperoleh jawaban dengan benar. $\mathrm{KC}$ juga menuliskan kesimpulan akhir pada hasil pengerjaan tes tetapi jawaban yang ditulis tidak menjawab permasalahan yang diberikan. Berdasarkan wawancara KC kebingungan dalam mengidentifikasi informasi yang diketahui pada soal. Sehingga KC menggerjakan menurut pemahaman sendiri. Kesulitan identifikasi masalah yang dialami mahasiswa sejalan dengan penelitian Ahmad \& Nasution, (2018), yang menyebutkan bahwa siswa yang tidak dapat menuliskan permasalahan dengan lengkap dan tidak dapat mengaitkan suatu permasalahan realistik kedalam model atau simbol matematik.

Temuan penelitian menunjukkan bahwa gaya belajar visual dan kinestetik memiliki kemampuan komunikasi ide matematis yang berbeda. Temuan ini sejalan dengan pernyataan Ardani \& Purwaningsih (2018) yang menunjukkan bahwa setiap karakteristik gaya belajar menunjukkan kemampuan komunikasi matematis yang berbedabeda. Hal ini dapat terjadi karena proses belajar juga dipengaruhi kenyamanan siswa dan kecenderungannya dalam menyimpan informasi. Penelitian Zahroh \& Asyhar, (2014) menyatakan bahwa model pembelajaran dengan dominasi audio kurang membantu mahasiswa yang bergaya belajar visual dan kinestetik. Dengan kata lain proses pembelajaran perlu memperhatikan kombinasi audio, visual dan aktifitas.

Temuan lainnya pada penelitian ini menunjukkan bahwa gaya belajar visual masih bisa beradaptasi dalam pembelajaran online yang didukung dengan terpenuhinya tiga dari empat indikator komunikasi ide matematis dari hasil tes dan wawancara. Indikator yang paling baik terpenuhi pada mahasiswa dengan gaya belajar visual adalah menuliskan prosedur penyelesaian masalah secara runtut dan jelas. Temuan ini tidak sejalan dengan hasil penelitian Wijayanti et al., (2019) yang menyatakan bahwa siswa dengan gaya belajar visual kurang dapat maksimal dalam menyampaikan ide melalui aljabar ataupun gambar. Perbedaan temuan ini dapat terjadi karena perbedaan subjek penelitian dimana artikel ini memiliki subjek mahasiswa yang cenderung lebih baik dalam prosedur. Selain itu proses pembelajaran di kelas juga akan mempengaruhi kemampuan siswa dalam menyatakan ide matematisnya.

Gaya belajar kinestetik pada penelitian ini menunjukkan kemampuan komunikasi ide matematis kurang baik yang ditunjukkan dengan tidak konsistennya mahasiswa dalam menyampaikan ide penyelesaian masalah. Mahasiswa kinestetik menuliskan informasi permasalahan, memilih prosedur benar dan menuliskan simpulan dengan benar pada satu atau dua jawaban soal saja. Hal ini dapat dikarenakan kegiatan pembelajaran online yang masih didominasi oleh media audio-visual sehingga kurang memfasilitasi gaya belajar kinestetik (Zahroh \& Asyhar, 2014). Ramdhan et al., (2020), menjelaskan bahwa bahwa gaya belajar pada pembelajaran online memiliki pola yang berbeda dalam belajar dan mengerjakan tugas. Dengan kata lain, mahasiswa gaya belajar visual kurang terfasilitasi dalam pembelajaran jarak jauh selama Pandemi.

Berdasar temuan penelitian, pembelajaran jarak jauh perlu memfasilitasi mahasiswa atau peserta 
didik bergaya belajar visual misalnya dengan memberikan penugasan berupa aktifitas percobaan, menggunakan media manipulative atau media aplikasi atau simulasi seperti GeoGebra. Kegiatan observasi dan analisis pada lingkungan sekitar (kontekstual) terkait permasalahan yang berkaitan dengan Geometri dapat membantu mahasiswa dengan gaya belajar kinestetik untuk belajar lebih baik. Temuan penelitian ini mendukung temuan penelitian lainnya yang menyatakan bahwa kegiatan pembelajaran dapat mempengaruhi kemampuan mahasiswa.

\section{KESIMPULAN DAN SARAN}

Kemampuan komunikasi ide matematis mahasiswa yang memiliki gaya belajar visual, pada pembelajaran online selama Pandemi, berada pada kategori baik. Mahasiswa dengan gaya belajar visual dapat memenuhi minimal 3 indikator kemampuan komunikasi ide matematis dalam menjawab semua soal geometri yang diberikan. Indikator komunikasi matematis berupa menyajikan prosedur penyelesaian masalah dengan jelas dan runtut merupakan indikator yang dapat dipenuhi oleh mahasiswa dengan gaya belajar visual. Kemampuan komunikasi ide matematis mahasiswa yang memiliki gaya belajar kinestetik, pada pembelajaran jarak jauh ketika Pandemi, berada pada kategori kurang. Mahasiswa dengan gaya belajar kinestetik memenuhi paling banyak 3 indikator kemampuan komunikasi ide matematis pada setiap soal Geometri yang diberikan.

Penelitian lebih lanjut terkait kemampuan komunikasi ide matematis dalam pembelajaran online dapat berupa pengembangan atau desain urutan tugas dalam kegiatan pembelajaran online yang memfasilitasi pengembangan kemampuan komunikasi ide matematis. Penelitian selanjutnya dapat difokuskan pada pemanfaatan media sehingga kegiatan pembelajaran jarak jauh dapat memfasilitasi setiap tipe gaya belajar.

\section{DAFTAR PUSTAKA}

Achir, Y. S., Usodo, B., \& Retiawan, R. (2017). Analisis Kemampuan Komunikasi Matematis Siswa Dalam Pemecahan Masalah Matematika Pada Materi Sistem Persamaan Linear Dua Variabel (Spldv) Ditinjau Dari Gaya Kognitif. Paedagogia, 20(1), 78. https://doi.org/10.20961/paedagogi a.v20i1.16600

Ahmad, M., \& Nasution, D. P. (2018). Analisis Kualitatif Kemampuan Komunikasi Matematis Siswa Yang Diberi Pembelajaran Matematika Realistik. Jurnal Gantang, 3(2), 83-95. https://doi.org/10.31629/jg.v3i2.47 1

Aisami, R. S. (2015). Learning Styles and Visual Literacy for Learning and Performance. Procedia Social and Behavioral Sciences, 176, 538-545. https://doi.org/10.1016/j.sbspro.20 15.01.508

An, D., \& Carr, M. (2017). Learning Styles Theory Fails to Explain Learning and Achievement: Recommendations for Alternative Approaches. Personality and Individual Differences, 7. https://doi.org/10.1016/j.paid.2017. 04.050

Anugrahana, A. (2020). Hambatan , Solusi dan Harapan : Pembelajaran Daring Selama Masa Pandemi Covid-19 Oleh Guru Sekolah Dasar. Scholaria: Jurnal Pendidikan Dan Kebudayaan, 10(3), 282-289. 
DOI: https://doi.org/10.24127/ajpm.v10i2.3642

https://doi.org/10.24246/j.js.2020.v 10.i3.p282-289

Ardani, A., \& Purwaningsih, D. (2018). Pengaruh Gaya Belajar Mata Kuliah Aritmatika (Jari Matika Dan Sempoa) Terhadap Kemampuan Komunikasi Matematis. JES-MAT (Jurnal Edukasi Dan Sains Matematika), 4(2), 95. https://doi.org/10.25134/jesmat.v4i2.1452

Bosni, Z., \& Nan, I. (2013). Computers \& Education Exploring the Relation Between Learning Style Models and Preferred Multimedia Types. Computers \& Education Journal, 69, 343-355. https://doi.org/10.1016/j.compedu. 2013.07.029

Daimaturrohmatin, D., \& Rufiana, I. S. (2019). Analisis Kemampuan Komunikasi Matematis Siswa Ditinjau Dari Gaya Belajar Kolb. Edupedia, $\quad 3(1), \quad 17$. https://doi.org/10.24269/ed.v3i1.23 2

Djunaedy, R. P. (2020). Penerapan Pembelajaran Online dengan Model Problem Based Learning untuk Meningkatkan Keaktifan Belajar Matematika Siswa Kelas XI MM 3 SMKN 5 Malang. Laplace: Jurnal Pendidikan Matematika, 3(2), 95-108. https://doi.org/10.31537/laplace.v3 i2.376

Farida, N. (2015). Analisis Kesalahan Siswa SMP Kelas VIII Dalam Menyelesaikan Masalah Soal Cerita Matematika. AKSIOMA: Jurnal Program Studi Pendidikan Matematika, 4(2), 1-27. https://doi.org/10.24127/ajpm.v4i2. 306

Ferdianto, F., \& Yesino, L. (2019). Analisis Kesalahan Siswa dalam
Menyelesaikan Soal Pada Materi SPLDV Ditinjau dari Indikator Kemampuan Matematis. SJME (Supremum Journal of Mathematics Education), 3(1), 3236.

https://doi.org/10.31235/osf.io/km wg6

Fitrah, M. (2017). Pembelajaran Berbasis Masalah Untuk Meningkatkan Pemahaman Konsep Matematika Materi Segiempat. Jurnal Pendidikan Matematika, 2(1), 51-70. https://doi.org/10.22236/KALAM ATIKA.vol2no1.2017pp51-70

Gitriani, R., Aisah, S., Hendriana, H., \& Herdiman, I. (2018). Pengembangan Lembar Kerja Siswa Berbasis Pendekatan Kontekstual pada Pateri Lingkaran untuk Siswa SMP. JRPM: Jurnal Review Pembelajaran Matematika, 3(1), 40-48. https://doi.org/10.15642/jrpm.2018 .3.1.40-48

Hamdani, D. Al. (2015). Exploring Students' Learning Style at a Gulf University: A Contributing Factor to Effective Instruction. Procedia Social and Behavioral Sciences, 176, 124-128. https://doi.org/10.1016/j.sbspro.20 15.01 .452

Hong, J. C., Lee, Y. F., \& Ye, J. H. (2021). Procrastination predicts online self-regulated learning and online learning ineffectiveness during the coronavirus lockdown. Personality and Individual Differences, 174(October 2020), 110673. https://doi.org/10.1016/j.paid.2021. 110673

Iriani, D., \& Leni, M. (2013). Identifikasi Gaya Belajar dan Pengaruhnya terhadap Hasi Belajar 
DOI: https://doi.org/10.24127/ajpm.v10i2.3642

Siswa pada Materi Kubus dan Balok di Kelas VIII SMPN 2 Kerinci. Prosiding Semirata FMIPA Unila, 1(1).

Kabael, T. (2012). Graduate Student Middle School Mathematics Teachers' Communication Abilities in the Language of Mathematics. Procedia - Social and Behavioral Sciences, 55, 809815.

https://doi.org/10.1016/j.sbspro.20 12.09.567

Khadijah, I. N. A., Rippi, M., \& Wahyu, S. (2018). Analisis Kemampuan Komunikasi Matematis Siswa SMP pada Materi Statistika. JPMI: Jurnal Pembelajaran Matematika Inovatif, 1(6), 1095-1104. https://doi.org/10.22460/jpmi.v1i6. p1095-1104

Kleden, M. A. (2013). Kemampuan komunikasi matematis dan Self Directed Learning Mahasiswa. Jurnal Matematika Dan Pendidikan Matematika, 2(2), 1420.

Loviana, S., \& Baskara, W. N. (2020). Dampak Pandemi COVID-19 pada Kesiapan Pembelajaran Tadris Matematika IAIN Metro Lampung. Epsilon, 1(2), 61-70. http://jurnal.stkippgribl.ac.id/index. php/epsilon/article/view/625

Masfingatin, T., Murtafiah, W., Krisdiana, I., Setyansah, R. K., \& Susanti, V. D. (2021). Multimodal Model Melalui E-Learning pada Mata Kuliah Geometri Bidang di Masa Pandemi COVID 19. AKSIOMA: Jurnal Program Studi Pendidikan Matematika, 10(1985), 1-2.

http://jpaus.jaranboston.org/?eid=9 57714

Masrifah, Setyowati, R. D., \& Happy, N. (2020). Analisis Kemampuan
Komunikasi Matematis Berdasarkan Gaya Belajar Visual. Euclid, 7(1), 1. https://doi.org/10.33603/e.v7i1.250 8

Maulah, S., A, F. N., \& Ummah, N. R. (2020). Persepsi Mahasiswa Biologi Terhadap Perkulihan Daring Sebagai Sarana Pembelajaran Selama Pandemi COVID-19. ALVEOLI: Jurnal Pendidikan Biologi, 1(2), 50-61. https://doi.org/10.35719/alveoli.v1i 2.6

Maulana, H. A., \& Iswari, R. D. (2020). Analisis Tingkat Stres Mahasiswa Terhadap Pembelajaran Daring Pada Mata Kuliah Statistik Bisnis di Pendidikan Vokasi. Jurnal Ilmiah Kependidikan, 14(1), 1730.

https://doi.org/10.30595/jkp.v14i1. 8479

Mishra, D. L., Gupta, D. T., \& Shree, D. A. (2020). Online TeachingLearning in Higher Education during Lockdown Period of COVID-19 Pandemic. International Journal of Educational Research Open, 100012. https://doi.org/10.1016/j.ijedro.202 0.100012

Moyer-Packenham, P. S., Lommatsch, C. W., Litster, K., Ashby, J., Bullock, E. K., Roxburgh, A. L., Shumway, J. F., Speed, E., Covington, B., Hartmann, C., Clarke-Midura, J., Skaria, J., Westenskow, A., MacDonald, B., Symanzik, J., \& Jordan, K. (2019). How Design Features in Digital Math Games Support Learning and Mathematics Connections. Computers in Human Behavior, 91, 316-332. https://doi.org/10.1016/j.chb.2018. 
DOI: https://doi.org/10.24127/ajpm.v10i2.3642

09.036

Nurmantoro, M. A. (2017). Pengaruh Kemampuan Awal, Kecerdasan Emosi dan Motivasi Belajar Terhadap Kemampuan Komunikasi Matematis Siswa. Prosiding Diskusi Panel Pendidikan, 1(1), 1-11.

Nurul, A, O., \& L. S., Z. (2019). Analisis Kemampuan Koneksi Matematis Dan Komunikasi Matematis Ditinjau Dari Kepercayaan Diri Siswa SMP. JPMI (Jurnal Pembelajaran Matematika Inovatif), 2(2), 57-64. https://doi.org/10.22460/jpmi.v2i2. p57-64

Paridjo, Waluya, B. S., \& Rochmad. (2018). Kemampuan Komunikasi Matematika Mahasiswa Dengan Group Investigation Ditinjau Dari Aktivitas Belajar. AKSIOMA : Jurnal Matematika Dan Pendidikan Matematika, 9(1), 79. https://doi.org/10.26877/aks.v9i1.2 338

Patricia, A. (2020). College Students' Use and Acceptance of Emergency Online Learning Due to COVID19. International Journal of Educational Research Open, 1-32. https://doi.org/10.1016/j.ijedro.202 0.100011

Penger, S., \& Tekavčič, M. (2009). Testing Dunn \& Dunn 's and Honey \& Mumford's Learning Style Theories: The Case Of The Slovenian Higher Education System. Management, 14(2), 1-20.

Putri, F. A. E., Syaiful, S., \& Siburian, J. (2021a). Kemampuan Berpikir Kritis Siswa pada Pembelajaran Online Inquiry dan Problem Based Learning Ditinjau dari Kemampuan Awal. Jurnal Cendekia: Jurnal Pendidikan Matematika, 5(1), 274-285. https://doi.org/10.31004/cendekia. v5i1.450

Putri, F. A. E., Syaiful, S., \& Siburian, J. (2021b). Kemampuan Berpikir Kritis Siswa pada Pembelajaran Online Inquiry dan Problem Based Learning Ditinjau dari Kemampuan Awal. Jurnal Cendekia: Jurnal Pendidikan Matematika, 5(1), 274-285. https://doi.org/10.31004/cendekia. v5i1.450

Ramadhan, I., \& Minarti, E. D. (2018). Kajian Kemampuan Komunikasi Matematik Siswa SMP Dalam Menyelesaikan Soal Lingkaran Pembelajaran Matematika Yang Memiliki IX SMP Pada Materi lingkaran. Journal of Mathematics Education IKIP Veteran Semarang, 2(2), 151-161. https://doi.org/10.31331/medives.v $2 \mathrm{i} 2.624$

Ramdhan, D. F., Nasihudin, Rohaniawati, D., \& Pratiwi, I. M. (2020). Tipologi Belajar Mahasiswa Pada Pembelajaran Daring. Journal of Chemical Information and Modeling, 8(9), $1-58$.

Rezaeinejad, M., Azizifar, A., \& Gowhary, H. (2015). The Study of Learning Styles and Its Relationship with Educational Achievement Among Iranian High School Students. Procedia - Social and Behavioral Sciences, 199, 218-224.

https://doi.org/10.1016/j.sbspro.20 15.07.509

Rizqi, A. A., Suyitno, H., \& Sudarmin. (2016). Analisis Kemampuan Komunikasi Matematis Ditinjau Dari Kepercayaan Diri Siswa Melalui Blended Learning. Unnes Journal of Mathematics Education Research, 5(1), 17-23. 
Saptika, Y. A., Rosdiana, F., \& Sariningsih, R. (2018). Analisis Kesalahan Siswa Dalam Menyelesaikan Soal Kemampuan Komunikasi Matematis Pada Materi Bangun Datar. JPMI (Jurnal Pembelajaran Matematika Inovatif), $\quad 1(5), \quad 873$. https://doi.org/10.22460/jpmi.v1i5. p873-880

Sari, A. R., \& Aripin, U. (2018). Analisis Kesalahan Siswa Dalam Menyelesaikan Soal Cerita Bangun Datar Segiempat Ditinjau Dari Kemampuan Pemecahan Masalah Matematik Untuk Siswa Kelas Vii. JPMI (Jurnal Pembelajaran Matematika Inovatif), 1(6), 1135. https://doi.org/10.22460/jpmi.v1i6. p1135-1142

Soflano, M., Connolly, T. M., \& Hainey, T. (2015). Learning style analysis in adaptive GBL application to teach SQL. Computers and Education, 86, 105-119.

https://doi.org/10.1016/j.compedu. 2015.02.009

Ulya, H., Rahayu, R., Kartono, \& Isnarto. (2019). Kemampuan Matematis Mahasiswa Dalam Penerapan Asesmen Koloboratif. Jurnal Ilmiah Kependidikan, 10(4), 113-120.

https://doi.org/https://doi.org/10.24 176/re.v10i1.4125

Uptegrove, E. B. (2015). Shared Communication in Building Mathematical Ideas : A Longitudinal Study. Journal of Mathematical Behavior, 1-25. https://doi.org/10.1016/j.jmathb.20 15.02.001

Wijayanti, D. I., Hariastuti, M. R., \& Yusuf, I. F. (2019). KEMAMPUAN KOMUNIKASI MATEMATIS SISWA DITINJAU
DARI GAYA BELAJAR. INDIKTIKA Jurnal Inovasi Pendidikan Matematika, 2(1), 6876.

https://doi.org/http://dx.doi.org/10. 31851/indiktika.v2i1.3429

Wijayanti, I. D., Hariastuti, R. M., \& Yusuf, F. I. (2019). Kemampuan Komunikasi Matematis Siswa Ditinjau dari Gaya Belajar. INDIKTIKA (Jurnal Inovasi Pendidikan Matematika), 2(1), 6876.

Zahroh, U., \& Asyhar, B. (2014). Kecenderungan Gaya Belajar Mahasiswa dalam Menyelesaikan Masalah Fungsi Bijektif. Jurnal Kebijakan Dan Pengembangan Pendidikan, 2(1), 72-81. https://doi.org/10.22219/jkpp.v2i1. 1738 